\title{
Benign Breast Adenomyoepithelioma
}

National Cancer Institute

\section{Source}

National Cancer Institute. Benign Breast Adenomyoepithelioma. NCI Thesaurus. Code C5144.

A benign, nodular tumor that arises from the breast parenchyma. It is characterized by the proliferation of myoepithelial cells around spaces that are lined by epithelial cells. Occasionally, adenomyoepitheliomas may undergo malignant transformation. 